\title{
Magnetic anomalies northeast of Cape Adare, northern Victoria Land (Antarctica), and their relation to onshore structures
}

\author{
D. Damaske, ${ }^{1}$ A. L. Läufer, ${ }^{1}$ F. Goldmann, ${ }^{1}$ H.-D. Möller, ${ }^{1}$ and F. Lisker ${ }^{2}$ \\ ${ }^{1}$ Bundesanstalt für Geowissenschaften und Rohstoffe, Postfach 510153, 30631 Hannover, Germany (detlef.damaske@bgr.de) \\ ${ }^{2}$ Universität Bremen, FB 5, Postfach 330440, 28334 Bremen, Germany
}

\begin{abstract}
An aeromagnetic survey was flown over the offshore region northeast of Cape Adare and the magnetic anomalies compared to onshore structures between Pennell Coast and Tucker Glacier. The magnetic anomalies show two nearly orthogonal major trends. NNW-SSE trending anomalies northeast of Cape Adare represent seafloor spreading within the Adare Trough. A connection of these anomalies to the Northern Basin of the Ross Sea is not clear. Onshore faults are closely aligned to offshore anomalies. Main trends are NW-SE to NNW-SSE and NE-SW to NNESSW. NNW-SSE oriented dextral-transtensional to extensional faults parallel the Adare Peninsula and Adare Trough anomalies. NE-SW trending normal faults appear to segment the main Hallett volcanic bodies.
\end{abstract}

Citation: Damaske,D., A.L.Läufer, F. Goldmann, H.-D.Möller, and F. Lisker (2007), Magnetic anomalies north-east of Cape Adare, northern Victoria Land (Antarctica), and their relation to onshore structures, in Proceedings of the $10^{\text {th }}$ ISAES, edited by A. K. Cooper and C. R. Raymond et al., USGS Open-File Report 2007-1047, Short Research Paper 016, 5 p.; doi: 10.3133/of2007-1047.srp016.

\section{Introduction}

Major marine fault systems (e.g., Tasman and Balleny fracture zones) between Australia and Antarctica trend approximately NW-SE, pointing towards the Antarctic continent. In northern Victoria Land (NVL), geomorphological features (e.g., Lillie, Rennick, and Matusevich glaciers) show similar trends, as do the Ross-orogenic terrane boundaries (Kleinschmidt and Tessensohn, 1987). It is therefore tempting to propose a connection between marine fractures and continental fault systems, although such marine structures do not continue into the adjacent continental crust.

Marine surveys and satellite observations indicate seafloor spreading and fracture zone arrays in the Southern Pacific Ocean. Onshore NVL, right-lateral faults represent the dominating Cenozoic tectonic elements in the Rennick and Matusevich glacier areas (Salvini et al., 1997; Rossetti et al., 2003; Kleinschmidt and Läufer, 2006). Aeromagnetic investigations in NVL exhibit several magnetic features that are aligned with these Cenozoic strike-slip systems and the older inherited structures (Ferraccioli and Bozzo, 1999) and are also aligned with the offshore structures. A positive magnetic anomaly follows the eastern flank of the Rennick Glacier (Damaske and Bosum, 1993). Another linear magnetic anomaly (Matusevich Line: Damaske and Bosum, 1993) was discovered west of USARP Mountains and could be traced over a distance of $>100$ $\mathrm{km}$ to the northwest up to the Matusevich Glacier tongue (Ferraccioli et al., 2003), and may extend beyond the survey's limit. All major magnetic anomalies and lineations in NVL and over the adjacent polar plateau show a general NW-SE trend and can be traced towards the coast and into the shelf region. A possible correlation of these onshore magnetic features with offshore structures might point to a direct relationship between the marine and continental structures, as postulated by Brancolini et al. (1997) and Salvini et al. (1997).

Within the frame of GANOVEX IX 2005/06, an aeromagnetic survey was flown (Fig.1) in order to relate structural observations in onshore NVL with offshore tectonic elements of similar age. The survey covered the offshore regions along the Pennell coast between Yule Bay and Cape Adare and the Adare Trough and its possible connection with the Northern Basin in the Ross Sea. It also allowed us to follow the Cape Hallett volcanics further north beyond Cape Adare, which is of major importance to understand the tectonic development of the Ross Sea embayment and its relation to the opening of the Tasman Gateway between Antarctica and Australia.

Cande et al. (2000) has discussed the marine magnetic anomalies and tectonic setting of the Adare Trough. However, some marine anomalies towards Cape Adare are not fully understood, especially the interpretation of magnetic anomalies 16-18 is unclear (Cande and Stock, 2006). They and Davey et al. (2006) link the southern Adare Basin to the Northern Basin. For convenience in this paper, the region of new oceanic crust formed at the Adare spreading centre and coinciding with the Adare Trough and Adare Basin will be referred to as the Adare Trough. The following major questions may be raised: (i) Are there any seafloor spreading anomalies between the south-western termination of the Adare Trough and the coast, or can this area be interpreted as a stretched part of the continental shelf? (ii) Is the Adare Trough terminated by the so-called Cape Adare Fault offshore NVL (Salvini et al., 1997), or does it continue into the Northern Basin? 


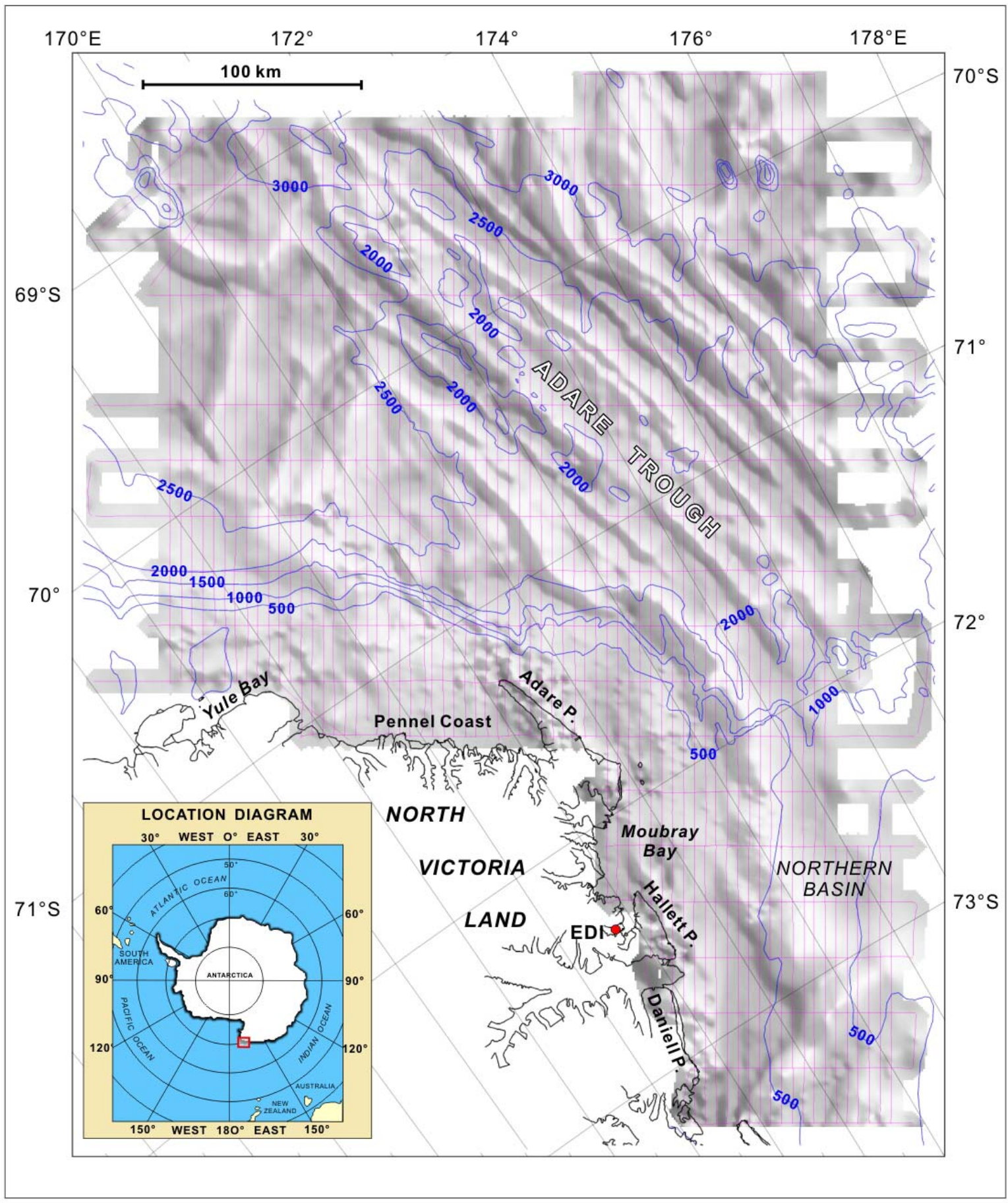

Figure 1. Flight line track (in red) and bathymetry (taken from GEBCO-97 Digital Atlas, in blue) superimposed on the anomaly map of Figure 2 (in grey shading).

\section{Survey set-up and data processing}

Survey parameters were chosen to allow comparison with previous aeromagnetic surveys in Victoria Land and the Ross Sea. The average distance to magnetic sources was expected to be in the order of $1-4 \mathrm{~km}$, except for the coastal areas where volcanics are at the surface. Flying at constantly $600 \mathrm{~m}$ a.s.l. (except for small sections directly over the coast where flights were performed in draped mode), a line spacing of $5 \mathrm{~km}$ was considered to meet the criteria of Bosum (1981). This spacing allows identification of the deeper crustal structures (long wavelength), but also provides adequate information on the shallower (high frequency) anomaly sources. It also allows sufficient coverage to place structures in a more 
regional context. The tie-line spacing of $25 \mathrm{~km}$ was chosen to account for the unusually high magnetic diurnal effects at high latitudes.

A De Havilland DHC-6-300 Twin Otter of Kenn Borek Air was contracted as the platform for the aeromagnetic survey. A Scintrex CS-2 magnetometer was used in a towed bird assembly. Measurements were made at $10 \mathrm{~Hz}$, corresponding to a ground interval of 6 to $9 \mathrm{~m}$, depending on aircraft speed. A total of 25665 $\mathrm{km}$ were flown covering an area of approximately

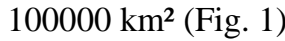

The magnetic diurnal variations were recorded at Edisto Glacier base camp (Figure 1) continuously from 24 November to 29 December 2005. The magnetically most disturbed intervals in a day were between 18 and $24 \mathrm{~h}$ UT. This compares well with earlier observations in NVL (Damaske, 1993; Damaske et al., 2001). To avoid this period of enhanced geomagnetic activity, a core period for the survey flights was chosen from 06h to $18 \mathrm{~h}$ UT corresponding to 19 to $7 \mathrm{~h}$ local time. The diurnal data sampled at 1 minute intervals were lowpass filtered over 30 minutes to remove the very high frequency signal. This was necessary due to the large distance between base station and survey area and the high level of diurnal activity present in Antarctica. The resulting filtered diurnal data were subtracted from the corresponding airborne magnetic readings. A correction for regional effects of the earth's magnetic field was made by calculating the IGRF (International Geomagnetic Reference Field) value at all survey points and at the survey altitude of $600 \mathrm{~m}$. The IGRF value was calculated using IGRF model 2005 at a mean date (12 December 2005) for all flights.

After removal of the diurnal variations and IGRF reduction, discrepancies between the magnetic field values at the intersections of profile- and tie-lines remained. The calculated deviations were minimized using an iterative levelling approach. In this way, not only the higher-frequency parts of the diurnal variation were accounted for, but also discrepancies due to differences in elevation were reduced. To account for obvious non-geological noise along the profile lines the data were microlevelled (Ferraccioli et al., 1998). Figure 2 shows the final microlevelled data with a sun-shade to enhance structural features.

\section{Magnetic structures}

The majority of magnetic anomalies in the survey area follows two main trends that are oriented approximately perpendicular to each other. Distinct anomalies of positive and negative amplitude are oriented parallel to each other and trend approximately NNW-SSE; these can be identified as the ocean-floor spreading pattern of the Adare Trough. In the northern section of the survey, ocean floor anomalies are oriented perpendicular or at a high angle to the Adare Trough. Towards the south, i.e. towards the continent, they seem to terminate close to the continental shelf break ( " $\mathrm{B}$ " in Figure 2) where small-scale anomalies occur. These anomalies are probably due to volcanics that are present relatively close to the surface on the continental shelf .

From Daniell Peninsula to Cape Adare, the Hallett volcanics produce a chain of high frequency, high amplitude magnetic anomalies (" $\mathrm{H}$ " in Figure 2). On this basis only about half of the volcanic rocks crop out and form the Daniell, Hallett, and Adare peninsulas, while the rest is covered by the Ross Sea. In addition, they also seem to extend towards the NNW for at least $130 \mathrm{~km}$. Hence the volcanics can be traced across the continental shelf and its slope into the deep oceanic areas. As the three volcanic peninsulas have slightly different orientations with regard to each other, so have their corresponding magnetic anomaly clusters.

The general trend of the Hallett volcanics from the southern tip of Adare Peninsula to the north including their underwater spur is interestingly oriented parallel to the Adare Trough anomalies. The Adare Trough anomalies seem to bend towards SSW at about $72^{\circ} \mathrm{S}$, and so does the magnetic cluster chain with the less apparent, but clearly distinguishable, continuation in Moubrae Bay. Further south, within the Hallett magnetic anomaly cluster, another change in direction, to the south, takes place. This is parallel to the inferred continuation of the western flank ("W" in Figure 2) of the Adare Trough. However, from our data it is not clear whether the Adare Trough's spreading anomalies are really curved. South of $72^{\circ} \mathrm{S}$, the distinct spreading pattern becomes less clear, with round-shaped, large anomalies ("M" in Fig. 2) of high positive amplitude intruding in this area. Also the expression of the central Adare Trough anomalies " $C$ " becomes interrupted and less clear. Unfortunately, some lines in the east which would have been crucial for investigating the continuation of the Adare Trough into the Northern Basin (Cande and Stock, 2006), could not be surveyed. The round-shaped anomalies " $M$ " point to deep extended sources that may be of the same type as the anomalies found in the Malta Plateau, Greene Point and Mt. Melbourne regions (Bosum et al., 1989).

Finally, in the southernmost section of the survey area, two large elongated anomalies "P" terminate the speculative extension of the western flank anomaly. Their orientation is approximately the same as those of the older of the ocean-floor spreading anomalies in the north. They resemble the Polar-3-anomaly and associated anomalies of the "Southern Cross magnetic unit" (Bosum et al., 1989) in shape and may be of the same origin. The high resolution of our survey also allows identification of a clear segmentation within the otherwise continuous anomaly pattern of the Adare Trough. The anomaly sequences on either side of the central anomaly of the trough have striking similar amplitude variations with breaks along strike at corresponding positions. 


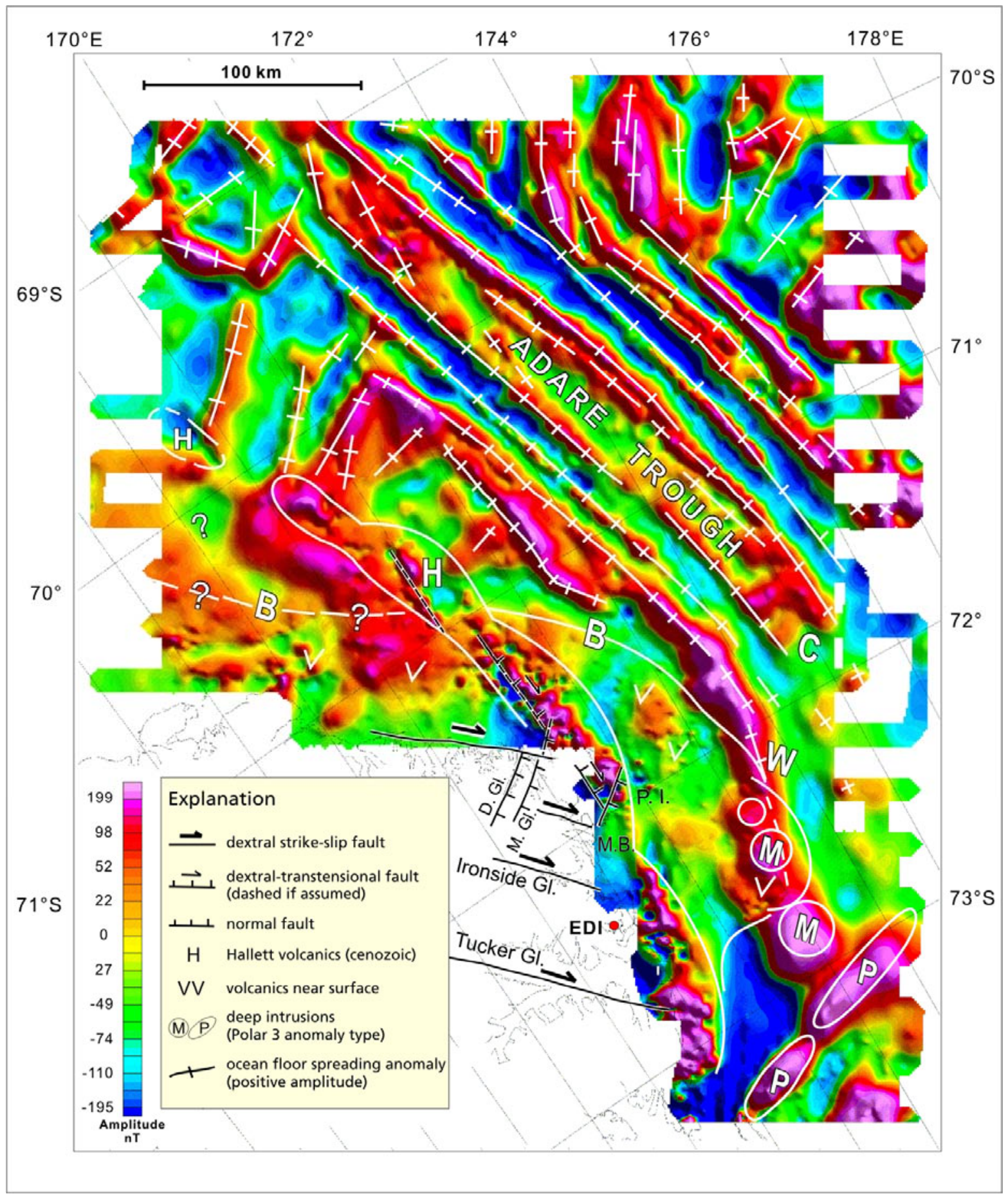

Figure 2. Anomaly map of the total magnetic field offshore Cape Adare. The sun shade has been cast from $45^{\circ}$ (survey grid orientation), at an inclination of $45^{\circ}$. This grid is displayed with an equal area colour scale. D.Gl., Dugdale Glacier; M.Gl., Murray Glacier; P.I., Possession Islands; M.B., Moubrae Bay; EDI, Edisto base camp.

\section{Onshore fault structures}

Structural mapping of brittle faulting in the onshore regions between Cape Adare and Cape Hallett adjacent to the aeromagnetic survey area reveals the presence of two main fault arrays. They are roughly perpendicular to each other and parallel the main glacial drainage systems indicating that the course of these glaciers is strongly influenced by the underlying tectonic architecture (Läufer et al., 2006).

NW-SE oriented major faults and NNW-SSE trending splay faults show dextral-transtensional kinematics and parallel the larger glaciers (e.g., Tucker and Ironside 
glaciers). The course of the Pennell coast between Cape Adare and Yule Bay is also controlled by dextral strikeslip faulting, too (Läufer et al., 2006). Hallett volcanic dykes intrude in faults of this system, but also contain dextral slickenlines and are off-set by dextral faults. This indicates that volcanism and tectonics are roughly contemporaneous. A major fissure that likely

coincides with a N-S striking dextral-transtensional to extensional fault is proposed to provide the pathway for the volcanic rocks forming the Adare Peninsula. A younger NNE-SSW to NE-SW striking extensional fault set parallels the Ross Sea coast and generally overprints and cross-cuts the Hallett volcanics, but is intruded by these rocks at other places. Examples are found along Dugdale and Murray glaciers (Figure 2), and they probably control the trend of the south-eastern termination of Adare Peninsula. The alignment of the small volcanic Possession Islands (Figure 1) may indicate the presence of a similar extensional fault that facilitated magma extrusion. Thus, faulting must be contemporaneous to or has outlasted Hallett volcanic activity.

\section{Conclusions}

The Adare Trough spreading anomalies are clearly defined and an internal structuring has been identified. Due to the (eastern) termination of the survey, however, it remains uncertain whether these spreading anomalies bend into the Northern Basin of the Ross Sea. The Hallett volcanics of the Adare Peninsula extend north into the continental shelf beyond Cape Adare. The existence of the Cape Adare Fault off the Pennell Coast (Salvini et al., 1997) is not confirmed by our aeromagnetic data. Onshore NVL, NW-SE to NNWSSE and NNE-SSW to NE-SW oriented faults between the Pennell Coast and Tucker Glacier are in alignment with offshore anomalies. The proposed NNW-SSE directed trans-/extensional fault that facilitated Hallett volcanics extrusion along the Adare Peninsula parallels the Adare Trough anomalies. This fault zone must continue further north into the shelf based on the aeromagnetically indicated extension of the volcanics into the offshore area beyond Cape Adare. The NNESSW to NE-SW oriented normal faults that apparently segment the volcanics of Adare, Hallett and Daniel peninsulas are possibly related to anomalies or breaks in the anomaly pattern of the same orientation on the continental side of the Adare Trough.

Acknowledgements. Sincere thanks to all those involved in field support of GANOVEX IX at Gondwana and Mario Zucchelli stations and our flight crews from Kenn Borek Air Ltd. and Helicopters New Zealand. F.L. acknowledges Deutsche Forschungsgemeinschaft for funding (LI 745/8) and BGR for invitation to the expedition. We would like to thank the reviewers Fausto Ferraccioli, Dietmar Müller and especially the co-editor Fred Davey for constructive suggestions helping to improve the manuscript.

\section{References}

Bosum, W. (1981), Anlage und Interpretation aeromagnetischer Vermessungen im Rahmen der Erzprospektion, Geologisches Jahrbuch, E20, 3-63.

Bosum, W., D. Damaske, N.W. Roland, J. Behrendt, and R. Saltus (1989), The GANOVEX IV Victoria Land/ Ross Sea Aeromagnetic Survey, Interpretation of Anomalies, Geologisches Jahrbuch, E38, 153-230.

Brancolini, G., M. Busetti, A.K.Cooper, F. Salvini, and F. Storti (1997), Cenozoic Tectonic Map of the Ross Sea Region, Antarctica. in The Antarctic Region: Geological Evolution and Processes edited by C.A. Ricci, 1163-1164.

Cande, S.C., J.M. Stock, R.D.Müller, and T. Ishihara (2000), Cenozoic motion between East and West Antarctica, Nature, 404 , 145-150.

Cande, S.C., and J.M. Stock (2006), Constraints of the timing of extension in the Northern Basin, Ross Sea, in Antarctica: Contributions to Global Earth Sciences edited by D.K. Fütterer, D. Damaske, G. Kleinschmidt, H. Miller, and F. Tessensohn, SpringerVerlag, Berlin Heidelberg New York, 319-326.

Damaske, D. (1993), Geomagnetic Activity in North Victoria Land during GANOVEX V, Geologisches Jahrbuch, E47, 103-114.

Damaske, D., and W. Bosum (1993), Interpretation of the Aeromagnetic Anomalies above the Lower Rennick Glacier and the Adjacent Polar Plateau West of the USARP Mountains, Geologisches Jahrbuch, E47, 139-152.

Damaske, D., E. Bozzo, D. Moeller, F. Ferraccioli, and M. Chiappini (2001), New Aeromagnetic Survey along Pennell, Oates and GeorgeV Coasts (East Antarctica), Terra Antartica Reports, 5, 1-12.

Davey, F.J., S.C. Cande, and J.M. Stock (2006), Extension in the western Ross Sea region -links between Adare Basin and Victoria Land Basin, Geophys. Res. Lett., 33, L20315, doi:1029/2006GL027383.

Ferraccioli, F., M. Gambetta, and E. Bozzo (1998). Microlevelling procedures applied to regional aeromagnetic data, an example from the Transantarctic Mountains (Antarctica), Geophys. Prospect., 46, 177-196.

Ferraccioli F., and E. Bozzo, (1999), Inherited crustal features and tectonic blocks of the Transantarctic Mountains: An aeromagnetic perspective (Victoria Land, Antarctica). J. Geophys. Res., 104: 25, 297-25, 319.

Ferraccioli, F., D. Damaske, E. Bozzo, and F. Talarico (2003), the Matusevich Aeromagnetic Anomaly over Oates Land, East Antarctica, Terra Antartica, 10(3), 221-228.

Kleinschmidt, G., and F. Tessensohn (1987), Early Paleozoic westward directed subduction at the Pacific margin of Antarctica, in Gondwana Six, Structure, tectonics, and geophysics, edited by G.D. McKenzie, Amer. Geophys. Union Monogr. Series, 40, 89105.

Kleinschmidt, G., and A.L. Läufer (2006), The Matusevich Fracture Zone in Oates Land, East Antarctica, in Antarctica: Contributions to Global Earth Sciences edited by D.K. Fütterer, D. Damaske, G. Kleinschmidt, H. Miller, and F. Tessensohn, Springer-Verlag, Berlin Heidelberg New York, 175-180.

Läufer, A.L., G. Kleinschmidt, F. Henjes-Kunst,F. Rossetti, and C. Faccenna (2006), Geological Map of the Cape Adare Quadrangle, Victoria Land, Antarctica, $1: 250$ 000, in German-Italian Geological Antarctic Map Programme (GIGAMAP), edited by P.C. Pertusati and N.W. Roland, BGR, Hannover.

Rossetti, F., A.L. Läufer, and F. Storti (2003), Structural architecture and tectonic evolution of the Rennick Graben (northern Victoria Land, Antarctica): insights into the Cenozoic tectonics of the Ross Sea region, Terra Antartica, 10(3), 141-156.

Salvini, F., G. Brancolini, M. Busetti, F. Storti, F. Mazzarini, and F. Coren (1997), Cenozoic geodynamics of the Ross Sea region, Antarctica: crustal extension, intraplate strike-slip faulting and tectonic inheritance.,J. Geophys. Res., 102, 24669-24696. 